\title{
The Implication of Xenophobic Violence on Nigeria-South Africa Relations
}

\author{
${ }^{1}$ Ismail Bello \& ${ }^{2}$ Sakariyau Rauf Tunde \\ ${ }^{I}$ School of International Studies \\ Universiti Utara Malaysia, Malaysia \\ ${ }^{2}$ Political Science Department, Nigeria Police Academy Wudil \\ Kano State, Nigeria \\ ismailbello12@gmail.com; sakrauf2002@yahoo.com \\ DOI: https://doi.org/10.32890/jis2017.13.8
}

\begin{abstract}
The renewed xenophobic attacks in South Africa on Nigerians and other Africans is an ugly trend that raises serious concern among experts and analysts of foreign relations. The latest scenario in Pretoria has resulted in the loss of innocent lives and valuable properties destroyed by some militant youths in South Africa. According to Nigeria's Foreign Affairs and Diaspora Advisor, Abike Dabiri-Erewa, the country has lost about 116 nationals due to the unlawful acts of some hoodlums in South Africa. This remains a significant setback and which poses a threat to the external relations of Nigeria and South Africa. The research relies on secondary data, such as journals, books, Internet materials, newspaper and official communications between South Africa and Nigeria. The ugly trend of xenophobic attack has resulted in a cold war between Nigeria and South Africa in their socio-economic and political relationships. However, the paper infers that adequate actions are required to be taken to restore and guarantee peace for the immigrants residing in South Africa. Failure to curb the menace of xenophobic violence in South Africa might degenerate into regional conflict which invariably will affect the relationship between both nations in all ramifications. The research contributes to existing literature on the issue of xenophobic attack and its impact on foreign relations; it also gives insight on the recent xenophobic attack which occurred in 2017 and its impact on Nigeria and South Africa relations.
\end{abstract}

Keywords: Foreign relations, xenophobia, apartheid, South Africa, Nigeria.

\section{Introduction}

The renewed xenophobic attacks in South Africa on Nigerians and other fellow African counterparts is an ugly trend that raises serious concern among experts and analysts of foreign relations. The February 22, 2017 scenario in Pretoria resulted in the loss of innocent lives and valuable properties destroyed by some militant youths in South Africa. According to Nigeria's senior special adviser on foreign affairs and diaspora, Abike Dabiri-Erewa, the 
country lost about 116 nationals between 2016 to 2017 due to the unlawful acts championed by some hoodlums in the host country (Salau, 2017). This remains a major setback and which poses a threat to the external relations of Nigeria and South Africa. The attacks and looting of goods belonging to Nigerian businessmen and women were confirmed by the President of the Nigerian Community in South Africa in the report issued by the News Agency of Nigeria. From the report, it was confirmed that over five buildings occupied by Nigerian business were burnt with unprecedented looting (NAN, 2017). This action is antithetical to immigration law and does not conform to the principle of fundamental human rights.

However, the long cordial relationship enjoyed by both countries in socio-economic and political partnerships might be compromised with the recent unfortunate uprising. Several stakeholders ranging from civil society groups, student unions and members of the Nigerian government have raised the alarm on the possibility of imposing stringent policies on the business and economic interests of South Africa situated in Nigeria. The Nigerian government has also called on the African Union to caution the host country on the criminal attacks that have claimed the lives of innocent Nigerians. Although, there have been promises from the South African government to investigate and bring the culprits to justice, the cold war between the two countries could be noticed through the statements and counter statements of their representatives on foreign mission.

Given this, it becomes imperative in this study to explore the issue of xenophobic violence in South Africa which has been targeted on Nigerians, Zimbabweans, Mozambicans and some other Africans in the country. With reference to Nigeria, the study hopes to analyse the implication of xenophobia on the Nigeria-South Africa relations. The paper comprises five sections. The first segment captures the general background information of the subject matter while the concept of xenophobia is clarified through the review of relevant literature regarding the phenomenon. The third section encompasses the manifestation of xenophobic attacks in South Africa while the fourth section looks at its implication on Nigeria- South Africa relations. The last segment contains concluding remarks and policy options required to tame the ugly monster of xenophobia attack in South Africa.

\section{The Concept of Xenophobia}

Literarily, xenophobia simply means unreasonable hatred for strangers or foreigners. It is an act where hatred and unfriendly attitudes are displayed towards foreigners or strangers by members of host communities (ref). Similarly, xenophobia indicates uncomfortable reactions to another person's culture and norms. This translates to absolute hatred for customs, dress, languages and other characteristics of different cultures (The American Heritage, 2005). According to the Oxford Dictionary, xenophobia is an extreme dislike of other people's culture, values and religion. 
The term, according to Watts (1996), has replaced racism in the European context. As it is known racism refers to biological and hereditary differences between races with the belief and perception that one race is superior to another (Miles \& Phizacklea, 1984); the modern perspective of racism has been linked with xenophobia. Though racism shares some similarities with xenophobia regarding hatred for some cultures and customs, the latter has become a contemporary extreme display of sentiment (Canetti-Nisim \& Pedahzur, 2003). In fact, it has become a new form of racism that is symbolic which poses a severe threat to cultural values and economic integration. In a nutshell, xenophobia is the contemporary form of racism which in Europe has been severally linked to political and ideological expressions. To Mudde (2007) the application of the term led to the discrimination between host communities and asylum workers. Nevertheless, xenophobia is all about hostility towards members of specific groups and nationals.

However, considering the xenophobia attack in South Africa, a term has been developed and used to differentiate the locals from foreigners particularly among other Africans. The derogatory term 'Amakwerekwere' implies a separation of South African nationals from other African members. This alone does not only violate the principle of human rights, it also violates the African spirit of humaneness. Given this, the view of Watts (1996) captures xenophobia beyond the immigration issue to an ideological conflict with the notion that anything alien is a threat. The phenomenon and dimension of xenophobic violence in South Africa could be likened to Watts' ideological realm which does not only subscribe to the primordial sentiment of religion and ethnicity but also denounces non-indigenous alliances. Put differently, Paul Boateng, former British High Commissioner to South Africa, laments that xenophobia is synonymous with racism. According to him, xenophobia attacks have always been carried out because of discrimination of colour and shades of skin. The scenario in South Africa, however, could not be justified on skin differences because most of the perpetrators of the xenophobia violence were blacks; their hostility towards other black men from neighbouring countries remains worrisome. The violence and attacks were not necessarily on skin differences like the case of apartheid; they were a socio-economic tussle with the mindset that foreigners are the hurdles occupying and hijacking limited resources in the country. That is why most of the areas attacked on xenophobia basis have commercial and economic values, and the targets have usually been foreigners involved in financial and business activities. This repels the idea of globalisation and African unity.

Finally, xenophobia violence remains an attack targeted at a group of people who may be within or outside a society but who are not considered to be members of the society. It is a systemic prejudice and discrimination which in extreme cases could be tagged 'genocide' (REF). Though not all hostility towards foreigners results in violence or attacks, xenophobia is an anti-immigration sentiment that often leads to social mayhem and violence on innocent immigrants. It is therefore important to understand the dimension of xenophobia in South Africa which has been targeting other Africans living in the country. It is on this basis that this paper explores the nature of xenophobia attacks on Nigerians in South Africa and its 
implication on the foreign relations of the two countries. To ascertain this, the next segment looks at the manifestation of xenophobic violence in South Africa with interest on Nigerian immigrants in the country.

\section{Manifestation of Xenophobia Attack on Nigerians in South Africa}

The ugly trend of xenophobic violence in South Africa which has often been targeted at Africans is not a new phenomenon in the country. However, the renewed recent attacks have generated serious tensions within and beyond the African continent. The manifestation of xenophobia attacks on Africans can be traced to 1995; youths in the Alexandra township of Johannesburg destroyed and looted the homes of undocumented migrants and subsequently marched the migrants to the police station where they requested that the foreigners be immediately deported to their home countries. The violent xenophobic attacks continued on migrants in 2008 when South Africans targeted immigrants from Mozambique, Zimbabwe, Malawi and other African countries, which resulted in attacks and looting of immigrants' homes and businesses, and killing more than twenty foreign nationals in just one week. By the time the violence subsided a total of sixty foreign citizens were killed and thousands displaced from their homes and businesses (Burchard, 2015).

The first manifestation of xenophobic attacks on Nigerians can be traced to August 2000, when seven Africans, among whom two Nigerians, were killed in the Cape flats in the district of Cape Town. Since then attacks on Nigerians have become norms for South Africans. In 2014, about sixty Nigerians were killed during attacks on Africans in South Africa. In 2016, twenty Nigerians were reportedly killed. They xenophobic attack was taken to greater heights with extra-judicial killings and police brutality which targeted Nigerians. In 2016, a 34-year-old Nigerian, Tochukwu Nnamdi, was extra-judicially murdered by the police. On $18^{\text {th }}$ February 2017, Nigerians in South Africans were attacked, leading to looting and burning of their business premises.

In a similar vein, on the same day, February 18, 2017, Nigerians living in Pretoria West were attacked by South Africans. The President of the Nigerian Union in South Africa, Mr Ikechukwu Ayene, confirmed the attacks. During the attack, five buildings occupied by Nigerian businessmen, a church belonging to Nigerians, and a garage with 28 cars under repair were looted and burnt by South Africans, leading to the injuries sustained by a Nigerian pastor. One common feature of the attack on Nigerian was that their shops and businesses were looted before being set ablaze (Salau, 2017). As on 27th February 2017, a total of one hundred and sixteen Nigerians were reported to have been killed in South Africa owing to xenophobic attacks. (Wakili \& Salau, 2017). Apart from the loss of innocent lives, Nigerians lost businesses and properties worth millions of dollars because of the ugly trend of xenophobic violence in South Africa. 


\section{Implication of Xenophobic Attacks on Nigeria-South African Relations}

Scholars and analysts have expressed concern about the consequence of xenophobic violence primarily perpetrated by some aggressive youths in South Africa on innocent black foreigners which invariably has resulted in a diplomatic cold war between Nigeria and South Africa. Given this, the two countries being larger economies in Africa have more to lose if the situation persists. Put differently, the severe attacks on Nigerians have been analyzed by experts to be an ungrateful reciprocation from South Africa owing to the fact that the former actively played a significant role in liberating the latter from the shackle of colonialism during the apartheid policy (Bello, Dutse, \& Othman, 2017; Chidozie, 2012; Dutse \& Bello, 2017; Dallaji, 2012; Onah, 2014; Zabadi \& Onuoha, 2012).

However, since the eradication of the apartheid policy in South Africa which enhanced better socio-economic and political opportunities for the black South Africans, the issue of the xenophobic attacks has been resurfacing, and the vulnerable individuals remain foreigners from fellow black countries ranging from Zimbabwe, Kenya, Uganda and Nigeria. Considering the Nigerian context, the crisis does not only threaten the cordial and bilateral relationship between her and South Africa, but it also challenges the Afrocentrism as a cardinal principle of Nigeria's foreign policy (Amao \& Uzodike, 2015). Though Nigeria is a dominant regional force in Africa, the issue of xenophobia could be another threat to its hegemony which has faced a serious setback due to action and inaction from neighbouring countries within the African continent. In lieu of this, the implication of the xenophobic attacks on Nigerians in South Africa can be categorised into two; Diplomatic or Political, and bilateral economic implications.

\section{BI-Lateral Economic Implication}

On the economic front, there are a lot of South Africa businesses operating in Nigeria in different sectors ranging from telecommunications, services, consumer goods, mining, agriculture, oil and gas, aviation, construction and hospitality. Some of these companies include MTN, Eskom Nigeria, South Africa Breweries, Power Gaint, Stanbic Bank, Eskom Nigeria, Refresh product, Shoprite and Multichoice among others. South Africa is said to be on the advantageous side with regards to bilateral relations because they are less Nigerian companies operating in the country (Folarin, Ibietan \& Chidozie, 2016). The implication was the attacks in Nigeria led to calls by the Nigerians for reprisal especially on South Africa's business interess in the country. When the government did not act on these, some youths took the law into their hands by attacking MTN, one of South Africa's businesses in Nigeria. As reported by the Nigerian Communication Commission (NCC), over fifty-four million subscribers make use of MTN which remains the largest telecommunication industry in Nigeria (NCC, 2017). Though there is a telecommunication company (GLOBACOM) owned by a Nigerian business icon, Mike Adenuga, which has spread its tentacles to some 
West African countries, the major distributing communication network in Nigeria is the MTN the ownership of which has been traced to South Africa.

Different groups in Nigeria have continued to threaten South African business interests. Among them are the Niger Delta militants. Their main grouse and the continuous xenophobic attacks on Nigerians who were carrying out their legitimate business in South Africa was uncalled for because South Africans in Nigeria were not under any form of attacks. One of the militant leaders pointed out that "It is so regrettable that a country and nationals that had enjoyed the greatest affection of Nigerians were now repaying such hospitality with mindless killing and brutality" (Ukwu, 2017:21)

While the Niger Delta youths issued a threat to disrupt South African businesses in Nigeria, Youths under the aegis of Nigerian students in a kind of reprisal attack shutdown the MTN headquarters office located in the Federal Capital Territory of Nigeria, the Abuja office on $23^{\text {rd }}$ February 2017. Though there was no report of any loss of lives or damage during the protest from some angry Nigerian youths, the activities of the telecommunication industry (MTN) were disrupted on that day which served as a spillover effect of the recorded ugly scenario in South Africa. Despite the quick response from the Nigerian government to ensure calmness, the operation of MTN was disrupted by the teeming Nigerian youths who accused the South African authority of negligence and lack of political will to guarantee the safety and security of Nigerians in South Africa. Given this, the indecent act of xenophobic violence tends to plunge the two countries into economic sabotage.

The viability of the bilateral economic relationship enjoyed by both countries can be drastically affected if the phenomenon of xenophobia is not adequately curtailed. In fact, both countries have a cordial relationship in divergent economic-related areas. The issue of xenophobic violence poses a threat not only to their economic ties but also to the sustainability of African peace and security. The two countries cannot afford to engage in unhealthy competitive cold war, the trend of Africans attacking fellow Africans in the name of xenophobia remains a barrier to the socio-economic growth of the two countries. In a nutshell, peaceful co-existence among Africans is not negotiable for any meaningful economic development to be achieved. Businesses and investments cannot strive in volatile environments, and the security threat posed by the severe attacks on Nigerians and other blacks in South Africa might lead to economic sabotage not only in the host country but also in the affected countries.

\section{Diplomatic and Political Implications}

The history of the diplomatic relationship between Nigeria and South Africa is beyond two decades. During the apartheid policy, Nigeria was one of the strong agitators against the white dominance in South Africa. In fact, the Nigerian government issued over 300 visas to South Africans to travel abroad during the struggle for blacks' recognition in the country. 
This was done to show her solidarity with the anti-apartheid movement in South Africa (Samuel, 2017). However, since the eradication of the apartheid policy in South Africa coupled with freedom of Nelson Mandela, the country witnessed political independence which allowed the citizens to control the socio-economic and political atmosphere of the country. Though Nigeria had previously maintained hegemony within the African continent, its hegemonic power has been challenged by South Africa and other neighbouring countries. Both countries have continuously competed with regards to the hegemonic responsibility on the continent. Despite being the continent's two largest economies that wield military and diplomatic powers, the relationship between both countries has been described as volatile in recent years (Carsten \& Igboeroteonwu, 2017).

The core issue of racial dislike and attack on the black foreigners widened the diplomatic row between the two countries. For instance, in Nigeria, various stakeholders in the country berated the action of the South Africans and even called for the severing of diplomatic ties with South Africa in the height of the xenophobic attacks. The recall of the Nigerian High Commissioner in South Africa was an expression of the country is dissatisfaction with the response of the South African government on the spread of hate and dislike for fellow Africans residing in South Africa. It was observed that the South African government had not really shown the political will to curb the menace which had resulted in the loss of innocent lives and properties destroyed. According to the Special Advisor to Nigeria's President on Diaspora matters, Abike Dabiri, the frequent attributed xenophobic attacks in South Africa could be ascribed to hate speeches and misinformation emanating from the political class in South Africa.In a similar vein, different stakeholders in Nigeria ranging from members of the legislative assembly, members of labour unions, the academia and other interest groups have called for diplomatic reprisal. One of the members of Nigeria's National Assembly Senator Gbenga Ashafa, Senate committee member on Foreign Affairs was quoted to have said: "I don't see us doing anything tangible by way of arresting these attacks without this government standing up and having some diplomatic reprisal" (ChannelsTV, 2017).

In the final analysis, the threat of xenophobia as entrenched within the South African communities could degenerate to a diplomatic row which cannot enhance the socioeconomic and political development of the continent. All hands are required on deck by the two governments to address the ugly situation and to ensure such a thing does not occur in the future. The consequence of xenophobic attacks could lead to serious security breach and breaking of laws and order if proactive actions are not taken to curtail the ugly trend.

\section{Conclusion}

The ugly trend of xenophobic attacks has resulted in a cold war between Nigeria and South Africa in their socio-economic and political relationships. However, the paper infers that adequate actions are required to be taken to restore and guarantee peace for the immigrants residing in South Africa. Failure to curb the menace of xenophobic violence in South 
Africa might degenerate into regional conflicts which invariably will affect the relationship between both nations in all ramifications. The research contributes to existing literature on the issue of xenophobic attacks and their impact on external relations. It also gives insight into the recent xenophobic attack which occurred in 2017 and its impact on the Nigeria and South Africa relations. However, to avert future occurrence, there is a need to adopt a proper mechanism by ensuring that severe punishment awaits whosoever perpetrates such actions. The governments of both countries should have a bilateral pact in the security of immigrants of any race.

\section{References}

Amao, O. B., \& Okeke-Uzodike, U. (2015). Nigeria, Afrocentrism, and conflict resolution: After five decades-how far, how well? African Studies Quarterly, 15 (4), 1-23.

Bello, I., Dutse, A.I, \& Othman, M. F. (2017). Comparative analysis of Nigerian foreign policy under Muhammadu Buhari's administration 1983-1985 and 2015-2017. Asia Pacific Journal of Education, Arts and Sciences. 4 (4), 43-52.

Burchard, S.M. (2015, April 30) Xenophobia: South Africa's successor to apartheid. Retrieved from https://www.ida.org/idamedia/Corporate/Files/Publications/ AfricaWatch/africawatch-Apr-30-2015-vol8.ashx

Canetti-Nisim, D., \& Pedahzur, A. (2003). Contributory factors to political xenophobia in a multi-cultural society: The case of Israel. International Journal of Intercultural Relations, 27 (3), 307-333.

Carsten, P. \& Igboeroteonwu, A. (2017, February 23) Nigerian student protesters demand South Africans leave the country. Retrieved from http://uk.reuters.com/article/uksafrica-nigeria-xenophobia-idUKKBN1621CU

Chidozie, F. (2012). Economic globalisation in the 21st century and Nigeria-South Africa relations: Prospects and challenges. African Journal of Humanities and Globalisation, 2 (1 \& 2), 55-85.

ChannelsTV. (2017, March 17). Nigerians Attacked Again in South Africa. Retrieved from https://www.channelstv.com/2017/03/17/nigerians-attacked-again-in-south-africa/

Dallaji, I. A. (2012). Nigeria-South Africa Relations: Partnership, reversed patronage or economic Imperialism. Nigeria and the World: A Bolaji Akinyemi Revisited (pp. 265283) Lagos: NIIA Publishing.

Dutse, A. I., and Bello, I. (2017). Fight against terrorism and eonomic development as key Nigeria's foreign policy objectives under Muhammadu Buhari 2015-2017. Asian Journal of Multidisciplinary Studies, 5 (9), 123-128.

Folarin, S. F., Ibietan, J., \& Chidozie, F. (2016). Nigeria and the BRICS: Regional dynamics in emerging economies' studies. Journal of South African Business Research. 2016 (2016), 1-13.

Miles, R., \& Phizacklea, A. (1984). White man's country: Racism in British politics. Longwood: Press Ltd. 
Mudde, C. (2007). Populist radical right parties in Europe.Cambridge: Cambridge University Press.

Nigeria Communications Commission. (2017, June 11). Market Share by Operator. Retrieved from http://www.ncc.gov.ng/stakeholder/statistics-reports/industry overview\#viewgraphs-tables-2

Onah, E. I. (2014). Nigeria: A country profile. Journal of International Studies, 10, 151162.

Salau, T. (2017, February 20). Nigerians Suffer Xenophobic Attack in South Africa Again. Retrieved from http://venturesafrica.com/xenophobic-attack-on-nigerians-insouthafrica/

Samuel, O. (2017, February 24). Xenophobia and Nigeria/South Africa relations. Retrieved from http://thenationonlineng.net/xenophobia-nigeriasouth-africa-relations/

Wakili, I., and Salau, A. (2017, February 21). Xenophobia: 116 Nigerians killed in S/ Africa - The Presidency. Retrieved https://www.dailytrust.com.ng/news/general/ xenophobia-116-nigerians-killed-in-s-africa--presidency/186130.html

Watts, M. W. (1996). Political xenophobia in the transition from socialism: Threat, racism, and ideology among East German youth. Political Psychology, 17, 97-126.

Zabadi, I. S., \& Onuoha, F. C. (2012). Nigeria and South Africa: Competition or Cooperation. Perspectives on Nigeria's National Politics and External Relations: Essays in Honour of Professor A. Bolaji Akinyemi (pp. 384-408) Ibadan: University Press PLC. 